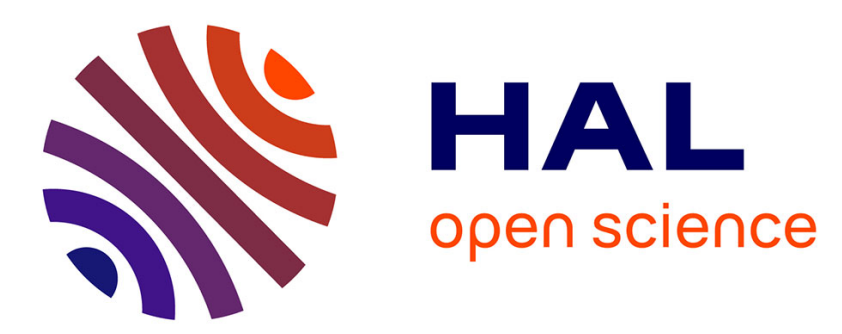

\title{
Observed volatilization fluxes of S-metolachlor and benoxacor applied on soil with and without crop residues
}

Carole Bedos, Lionel Alletto, Brigitte Durand, Olivier Fanucci, Aurore Brut,

Marjolaine Deschamps, Simon Giuliano, Benjamin Loubet, Eric Ceschia, Pierre Benoit

\section{To cite this version:}

Carole Bedos, Lionel Alletto, Brigitte Durand, Olivier Fanucci, Aurore Brut, et al.. Observed volatilization fluxes of S-metolachlor and benoxacor applied on soil with and without crop residues. Environmental Science and Pollution Research, 2017, 24 (4), pp.3985-3996. 10.1007/s11356-016-81249. hal-01531717

\author{
HAL Id: hal-01531717 \\ https://hal.science/hal-01531717
}

Submitted on 23 Sep 2021

HAL is a multi-disciplinary open access archive for the deposit and dissemination of scientific research documents, whether they are published or not. The documents may come from teaching and research institutions in France or abroad, or from public or private research centers.
L'archive ouverte pluridisciplinaire HAL, est destinée au dépôt et à la diffusion de documents scientifiques de niveau recherche, publiés ou non, émanant des établissements d'enseignement et de recherche français ou étrangers, des laboratoires publics ou privés. 


\title{
Observed volatilization fluxes of $S$-metolachlor and benoxacor applied on soil with and without crop residues
}

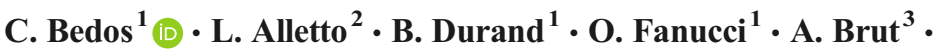 \\ M. Bourdat-Deschamps ${ }^{1} \cdot$ S. Giuliano ${ }^{2} \cdot$ B. Loubet $^{1} \cdot$ E. Ceschia $^{3} \cdot$ P. Benoit ${ }^{1}$
}

\begin{abstract}
Volatilization may represent a major dissipation pathway for pesticides applied to soils or crops, and these losses may be modified by soil surface conditions or in the presence of plant residues. This paper investigates the effect of surface conditions on volatilization through experimental results. The two experiments consisted of volatilization flux measurements for 3 days after an application of $S$-metolachlor together with benoxacor: one with two wind tunnels to compare the effect of the presence of crop residues on the soil on volatilization losses and another one at the field scale from bare soil without crop residues. Volatilization fluxes were large immediately after application (between 77 and $223 \mathrm{ng} \mathrm{m}^{-2} \mathrm{~s}^{-1}$ for $S$-metolachlor depending on experimental conditions), decreasing down to a few nanograms per square meter per second on the last day. Volatilization fluxes followed a diurnal cycle driven by environmental conditions. The losses found for both compounds were in accordance with their physicochemical properties. The crop residue on the soil surface modified soil surface conditions - primarily the soil
\end{abstract}

C. Bedos

Carole.Bedos@inra.fr

1 UMR ECOSYS INRA, AgroParisTech, Université Paris-Saclay, 78850 Thiverval-Grignon, France

2 INPT-Ecole d'ingénieurs de Purpan, UMR 1248 AGIR, Université de Toulouse, 75, voie du TOEC, BP 57611, 31076 Toulouse, France

3 CESBIO - UMR 5126, Université de Toulouse, 18 avenue E. Belin, 31401 Toulouse Cedex 9, France water content essentially, the degradation of $S$-metolachlor, and the dynamics of volatilization loss.

Keywords Pesticide $\cdot$ Emission $\cdot$ Crop residues $\cdot$ Soil $\cdot$ Wind tunnel $\cdot$ Field

\section{Introduction}

Reducing tillage intensity leads to significant and complex changes in the soil. Physicochemical properties and biological activities are interrelated with each other and thus can affect the fate of applied pesticides (Alletto et al. 2010). Furthermore, depending on mobility and persistence, pesticides can move away from the intended target, i.e. soil domain, and contaminate other components of the environment, such as water and air. The three main transport processes are volatilization, leaching, and runoff. The relative importance of each of these processes depends in particular on the application conditions, pesticide properties, climatic conditions, and soil properties that are influenced by agricultural practices.

Among these transport processes, volatilization is probably the least understood. When the application is done on a bare soil, the volatilization process is controlled by the pesticide properties such as the compound-saturated vapor pressure, Henry constant, $K_{\mathrm{OC}}$, soil properties (temperature, water content, organic carbon content), farming operations (mode of application, soil roughness, presence of plant residues), and local meteorological conditions (wind, solar radiation, temperature, rain) (Bedos et al. 2002a). Although volatilization is often mentioned in the literature to explain differences in pesticide persistence due to tillage operations (Banks and Robinson 1982; Curran et al. 1992; Gaynor et al. 2000), this phenomenon, especially its intensity and its occurrence, also 
remains poorly understood. Whang et al. (1993) highlighted higher pesticide volatilization in conservation tillage than in conventional tillage which was attributed to the accumulation of organic residue on the soil surface forming a mulch effect. In their study, 4 days after application, transport by volatilization accounted for 48 and $18 \%$ of applied fonofos, 23 and $7 \%$ of applied chlorpyrifos, and 0.9 and $0.7 \%$ of applied atrazine under no tillage and conventional tillage, respectively. The presence of organic residue at the soil surface may lead to greater interception of the applied pesticides (Locke 1992; Reddy and Locke 1998; Zablotowics et al. 2000), which could remain more available for a transport to the air from plant residues than from soil. Pesticide interception by crop residues strongly depends on the amount and type of crop residues (Banks and Robinson 1982; Ghadiri et al. 1984; Isensee and Sadeghi 1994; Sadeghi and Isensee 1997) and may thus modify the intensity of pesticide volatilization from plant residue. Wienhold and Gish (1994) observed a larger volatilization of alachlor and atrazine under conservation tillage but only until the first rainfall occurred (5 days after application). Following this rainfall, volatilization in conservation tillage was significantly reduced which could be explained by the transport of the pesticides from the plant residues to the soil. This wash-off of pesticides from plant residues to soil is known to mainly depend on the timing between pesticide treatment and the first rainfall and intensity. This wash-off was for example found to be the highest after a heavy rainfall occurring within 2 weeks following the application (Sadeghi and Isensee 1996, 1997). After 35 days, the cumulative volatilization loss accounted for 9 and $14 \%$ of applied alachlor and 4 and $9 \%$ of applied atrazine under conservation tillage and conventional tillage, respectively (Wienhold and Gish 1994). In addition, this later study showed a significant effect of pesticide formulation on volatilization. Starch-encapsulated alachlor was less volatile under conservation tillage than the commercial formulation, and a similar effect was measured for atrazine under both conservation tillage and conventional tillage systems.

Volatilization also directly depends on environmental conditions and is enhanced first by high soil surface temperatures (Glotfelty 1987; Weber et al. 2002) and by high water content that increase pesticide availability in the soil water solution. In dry soil, an additional process can play an important role in driving pesticide volatilization by governing the active ingredient (a.i.) concentration in the air of the soil pore space: the adsorption from the gaseous phase to the soil matrix (Goss et al. 2004) which may lead to a large decrease in volatilization and may also modify the diurnal volatilization flux (Garcia et al. 2014). Thus, any modification of the soil surface conditions may have an impact on the volatilization flux. In conservation tillage, the presence of plant residues on the soil surface tends to decrease evaporation (Drury et al. 1999) and soil temperature fluctuations (Wahl and Stobbe 1984). Compared to conventional tillage, soil warming under conservation tillage is generally slower (Drury et al. 1999; Gupta et al. 1988). In such cases (conservation tillage), water content in the topsoil horizon is generally higher (Fortin 1993) due to decreased water evaporation and increased soil water holding capacity (Bescansa et al. 2006; Miyamoto et al. 2001; $\mathrm{Xu}$ and Mermoud 2001). Both conditions can significantly modify pesticide volatilization rates (Bedos et al. 2010). Weber et al. (2006) observed that 128 days after application, volatilization reached 22 and $32 \%$ of applied metolachlor in conservation and conventional tillage, respectively. In that case, due to the plant residues, soil surface water content was greater under conservation tillage which lowered soil warming and thus reduced the amount of herbicide lost.

In the end, the volatilization flux is strongly correlated with the concentration of the compound in gaseous form at the soil surface which is in turn strongly governed by physicochemical equilibria within the soil. The adsorption from the aqueous phase to the soil matrix is often described by a partitioning coefficient between the aqueous phase and organic matter, even if, as previously mentioned, the adsorption from a gaseous phase has to be also considered under dry conditions. Sorption on plant residues is expected to be different compared to sorption within the soil as shown for $S$-metolachlor by Alletto et al. (2013). It also depends on plant residue decomposition (Aslam et al. 2013).

This short overview shows that the interactions between the volatilization processes with the overall behavior of the compounds are complex and potentially governed by the environmental conditions which may be modified by the plant residue presence on the soil surface. It is therefore required to carry out studies to analyze specifically the effect of crop residues at the soil surface on pesticide volatilization, all other conditions being monitored or as far as possible controlled.

This study focuses on two experiments that analyze the impact of the presence of crop residues on the soil surface on $S$-metolachlor volatilization flux. $S$-metolachlor [2chloro- $N$-(2-ethyl-6-methylphenyl)- $N$-(methoxy-1methylethyl) acetamide] (SMOC) is a selective chloroacetamide herbicide widely used for pre- and postemergence weed control for a variety of crops including maize, soybean, sunflower, and sorghum (Alletto et al. 2013). Data on metolachlor volatilization from bare soil together with the effect of surface soil water and local meteorological conditions can be found in the literature (Rice et al. 2002; Prueger et al. 2005; Gish et al. 2009). However, studies focusing on the effect of crop residues on the soil surface on volatilization flux of $S$-metolachlor are scarce even if, when $S$ metolachlor is applied in the field, the presence of crop residue on the soil surface may be common. The only publication found provided estimated volatilization losses by a mass balance approach, so without any direct measurement of the volatilization rate, calculated 128 days after application using 
${ }^{14} \mathrm{C}$ ring-labeled metolachlor applied on lysimeters (Weber et al. 2006). Commercial product with $S$-metolachlor often also contains benoxacor. As the benoxacor is expected to show a significant volatilization rate given its Henry law constant and in order to compare the behavior of $S$-metolachlor to the benoxacor behavior, this study focuses on both compounds.

The first experiment carried out for this study was conducted with two wind tunnel systems placed in the same field, one on a bare soil and the other on a soil partially covered with a crop residue consisting of maize and cover crop residue resulting from previous crops. Such systems were previously used to measure trifluralin volatilization rates (Bedos et al. 2002b). To complete this analysis and obtain a dataset at the field scale, a second experiment was also conducted on a bare soil without crop residue in a field close to the wind tunnel site. For each experiment, volatilization rates, together with additional environmental conditions, were measured for 3 days after herbicide application.

\section{Material and methods}

\section{Experimental setup}

In each experiment, $S$-metolachlor was applied at a recommended rate of $1500 \mathrm{~g} \mathrm{ha}^{-1}$ of active ingredient. It was provided as a mixture with benoxacor and mesotrione of commercial solution (Calibra, SYNGENTA Agro SAS, liquid) with a concentration of 400,20 , and $40 \mathrm{~g}$ active ingredient per liter (a.i. $\mathrm{L}^{-1}$ ), respectively. Physicochemical characteristics of $S$-metolachlor and benoxacor ingredients are provided in Table 1. Mesotrione was not analyzed as it was expected to show insignificant volatilization losses given its low vapor pressure and Henry's law constant (5.7E-06 Pa and 5.1E$07 \mathrm{~Pa} \mathrm{~m}^{3} \mathrm{~mol}^{-1}$, respectively).

Table 1 Physicochemical properties of ingredients - metolachlor and benoxacor (from Agritox)

\begin{tabular}{llll}
\hline & Unit & S-metolachlor & Benoxacor \\
\hline CAS number & - & $87392-12-9$ & $98730-04-2$ \\
Molecular mass & $\mathrm{g} \mathrm{mol}^{-1}$ & 283.8 & 260.1 \\
Vapor pressure & $\mathrm{Pa}$ & $3.7 \mathrm{E}-03\left(25^{\circ} \mathrm{C}\right)$ & $5.9 \mathrm{E}-04\left(20^{\circ} \mathrm{C}\right)$ \\
Water solubility & $\mathrm{mg} \mathrm{L}^{-1}$ & $480\left(25^{\circ} \mathrm{C}\right)$ & $20\left(20{ }^{\circ} \mathrm{C}\right)$ \\
Henry's constant & $\mathrm{Pa} \mathrm{m}^{3} \mathrm{~mol}^{-1}$ & $2.2 \mathrm{E}-03\left(25^{\circ} \mathrm{C}\right)$ & $7.7 \mathrm{E}-03\left(20^{\circ} \mathrm{C}\right)$ \\
$K_{\text {oc }}$ soil & $\mathrm{m}^{3} \mathrm{~kg}^{-1}$ & $0.206^{\mathrm{a}}$ & $0.042-0.177$ \\
$K_{\text {oc }}$ crop residue & $\mathrm{m}^{3} \mathrm{~kg}^{-1}$ & $0.062-0.118^{\mathrm{b}}$ & No information \\
\hline
\end{tabular}

${ }^{\mathrm{a}}$ From Alletto et al. (2013)

${ }^{\mathrm{b}}$ From Aslam et al. (2013)

\section{Wind tunnel experimental setup}

The wind tunnel consists of a $1-\mathrm{m}^{2}$ experimental surface $(0.50 \times 2 \mathrm{~m})$ covered by an inverted U-shaped polycarbonate sheet (transparent to solar radiation for wavelengths above $400 \mathrm{~nm}$, Fig. S1 left of Supporting Information). The air flow rate imposed inside the tunnel corresponds to a realistic wind velocity, close to $1 \mathrm{~m} \mathrm{~s}^{-1}$. Climatic conditions (air flow rate, air and soil surface temperatures, water evaporation, soil water content, see below) were checked inside the tunnel to ensure they were as close to outside conditions as possible (see Genermont et al. 1998a; Loubet et al. 1999a, b for additional tests on sampling methods in the duct or analysis of the turbulence regimes within the wind tunnel). The volatilization flux, $F\left(\mathrm{ng} \mathrm{m}^{-2} \mathrm{~s}^{-1}\right)$, is determined by the mass balance equation:

$F=Q\left(C_{\mathrm{o}}-C_{\mathrm{i}}\right) / S$

where $C_{\mathrm{i}}$ and $C_{\mathrm{o}}\left(\mathrm{ng} \mathrm{m}^{-3}\right)$ are the pesticide concentrations at the tunnel inlet and outlet, respectively, $Q\left(\mathrm{~m}^{3} \mathrm{~s}^{-1}\right)$ the air flow rate through the wind tunnel, and $S\left(\mathrm{~m}^{2}\right)$ the soil area covered by the tunnel. In this approach, the turbulent component of the horizontal flux is neglected. $C_{\mathrm{i}}$ and $C_{\mathrm{o}}$ are determined by sampling the mean air flow in the wind tunnel.

The experiment was conducted from 06:18 (UT) 25 April (day 116) to 17:30 (UT) on 27 April 2012 (day 118). Two wind tunnels were placed on the experimental farm of Lamothe (INPT-EI Purpan, Toulouse, France). Since 2011, the farm supports a field experiment on experimental plots of $12 \mathrm{~m} \times 60 \mathrm{~m}$ designed to test the sustainability of low-pesticide cropping systems proposed as "alternatives" to an irrigated continuous maize system (Giuliano et al. 2016). The first tunnel (T-MM1) was placed on the conventional maize monoculture reference plot (named MM1). This maize production system was designed to maximize the profitability, according to the conventional system practiced in the southwest of France, and its main agricultural operations consisted of a spring mouldboard plowing and a soil maintained bare during the fallow period in winter. The second tunnel (T-MM3) was placed at around $15 \mathrm{~m}$ from the first one, on the conservation tillage maize monoculture system (named MM3) including a cover crop (oat-vetchphacelia) during the fallow period and residues after cover crop destruction normally found in production agriculture such as corn. The soil is a stagnic Luvisol according to IUSS Working Group WRB (2007). Slight variations in soil texture exist among plots - a clay loam with $22.6 \%$ sand, $45.2 \%$ loam, $32.2 \%$ clay for MM1 and a silty clay loam with $13 \%$ sand, $47.2 \%$ loam, and $39.8 \%$ clay for MM3. The organic matter content was for MM1 (and MM3, respectively): $2.38 \%$ (2.41\% for MM3) between 0 and $10 \mathrm{~cm}$ and $1.85 \%$ (2\% for MM3) between 10 and $30 \mathrm{~cm}$. At the time of pesticide application, MM1 consisted of a bare soil and MM3 soil was covered by 
maize and cover crop residues (estimated to be between 40 and $55 \%$ coverage and between 1.2 and $1.4 \mathrm{tha}^{-1}$ ). Just before pesticide application, the area around the tunnels was covered with plastic canvas to protect the external soil surface and avoid any contamination of the inlet by volatilization outside the tunnels. The pesticide was applied as a knapsack sprayer over the two experimental surfaces, in compliance with normal agricultural practices. It was conducted at $1 \mathrm{~ms}^{-1}$ using a ramp with four commonly used nozzles. The remaining surface of the plots was not treated. The wind tunnels were closed within $15 \mathrm{~min}$ after application, and air sampling was started. $S$ metolachlor and benoxacor concentrations were measured at the outlet of each tunnel and, as the outside $S$-metolachlor and benoxacor concentrations were expected to be similar for both tunnels, the concentration at the tunnel inlet was sampled for only one tunnel. The sampling periods were variable, as summarized in Table S1 of the Supplemental Information, dictated by a compromise between analysis requirements and desired temporal resolution.

Soil water evaporation was monitored by measuring the difference in air water vapor pressure between the inlet and outlet of each tunnel. The air flow rate was calculated from the wind velocity using a hot film anemometer (EE65, Intertechnique) introduced into the duct of T-MM1 and two systems introduced into the duct of T-MM3 (a hot film anemometer (EE75, Intertechnique) and a Pitot anemometer, (CP301-BNP Kimo instruments)). Air and soil surface temperatures were monitored using one and five thermocouples (copper/constantan), respectively, per tunnel. In T-MM3, the thermocouples were fixed on the soil surface below the crop residue. All data were measured every $5 \mathrm{~s}$ and averaged on 15min intervals using a data logger (Campbell CR10, Campbell Scientific, UK). Outside meteorological conditions were monitored by a meteorological mast located close to the wind tunnels and measured air temperature, wind speed and direction, solar radiation, relative humidity, and rain, averaged at an hourly time scale. Soil water content was estimated at 0 $0.05 \mathrm{~m}$ using the gravimetric method before the experiment outside the experimental surfaces and at the soil surface $(0-$ $0.02 \mathrm{~m}$ ) at the end of the experiment inside both wind tunnels. Additional soil moisture monitoring was conducted using time-domain reflectometer (TDR) sensors (Soil Moisture, Santa Barbara, California) placed close to each tunnel at 0.05- and 0.10-m depths.

\section{Field experiment setup}

The experimental site of Lamasquère is located on the experimental farm of Lamothe (INPT-EI Purpan, Toulouse, France) $\left(43^{\circ} 29^{\prime} 47^{\prime \prime} \mathrm{N} / 1^{\circ} 14^{\prime} 16^{\prime \prime}\right.$ E, Fig. S1 right of Supplemental Information), with a total area of 32.3 ha. The soil is a clayey soil ( $12.0 \%$ sand, $33.7 \%$ loam, $54.3 \%$ clay), with an organic matter content of $2.78 \%$ between 0 and $30 \mathrm{~cm}$ and $1.74 \%$ between 40 and $50 \mathrm{~cm}$. The field is one of the experimental sites of the ICOS network (FR-LAM) in which the energy budget, soil temperature, and water content at different depths and three locations within the field are continuously monitored. Further information on the site and measurements can be found in Tallec et al. (2013). Maize crop was sown on the 27 April 2012, and its height was estimated around $0.05 \mathrm{~m}$ at the time of pesticide application on 15 May 2012.

Additional measurements have been carried out for the purpose of this experiment: for soil water content measurements, soil was sampled in the $0-0.01-\mathrm{m}$ layer with a trowel and in the $0-0.02-\mathrm{m}$ layer with a ring, and TDR were placed at $0.05 \mathrm{~m}$ depth; for bulk density estimation, soil was sampled in the first $0-0.05-\mathrm{m}$ layer using a ring of $250 \mathrm{~cm}^{3}$ (three replicates) and soil surface temperature was measured with five thermocouples (measured every $5 \mathrm{~s}$ and averaged on $30 \mathrm{~min}$ ).

Pesticide application took place between 8:26 UT and 12:00 UT on the morning of 15 May 2012 (day of year (DOY) 136) at a spraying rate of $120 \mathrm{~L} \mathrm{ha}^{-1}$.

The FIDES-2D model (Loubet et al. 2009, 2010) was used in an inverse mode to estimate the volatilization rates of both compounds during the three following days. In direct mode, FIDES-2D predicts the atmospheric concentrations and the gaseous deposition downwind of an emission area, given the local meteorological conditions and the source strength. It has been used to estimate local advection fluxes of ammonia downwind of an intensive source (Loubet et al. 2009, 2001). In inverse mode, it predicts the volatilization fluxes using the local meteorological conditions and the concentration at one height above the emitting field. Briefly, the inverse FIDES-2D model is a coupled dispersion and surface exchange model that combines a Gaussian-like dispersion model with a resistance analogy surface exchange model. The dispersion model is based on the Philip (1959) solution of the advection-diffusion equation, which assumes power law profiles for the wind speed and the diffusivity in the vertical direction. The compound is assumed to be conservative (no chemical reactions in the gas phase). The model assumes homogeneity of the surface (roughness length, wind speed, and diffusivity profiles are independent of horizontal location). The dispersion model is detailed in Huang et al. (1979) and Loubet et al. (2010). The surface exchange model includes an aerodynamic and a boundary layer resistance as described in Loubet et al. (2001). The FIDES-2D model has been positively evaluated against measured ammonia fluxes with the aerodynamic gradient method and the REA method (Loubet et al. $2009,2010)$ as well as against pesticide volatilization rate measured with the aerodynamic gradient method after application on bare soil (Loubet et al. 2006) and after fungicide application on wheat (Bedos et al. 2010). In this study, FIDES-2D was used to calculate the volatilization fluxes using (1) the concentration measured in the field (at $1.57 \mathrm{~m}$ above the soil), (2) the upwind concentration measured at 
$1.77 \mathrm{~m}$ height, (3) the roughness length $z_{0}$ (estimated at 5 . $10^{-3} \mathrm{~m}$, value obtained given the relationship based on $10 \%$ of the crop height), (4) the displacement height $d(0.04 \mathrm{~m})$, and (5) the friction velocity $u *$ estimated from momentum.

\section{Pesticide sampling}

The $S$-metolachlor together with benoxacor concentrations in the spraying solution were determined by sampling the solution before application. Then, the application dose was determined by placing filters (Whatman, GF/B, $90 \mathrm{~mm}$ diameter), just before the application, in Petri dishes at both sides of each tunnel (six filters per tunnel) or placed randomly in the field (12 filters). The filters were collected immediately after application, pooled per six and introduced into glass flasks tightly sealed with a screw cap and PTFE seal.

Ambient air was sampled for pesticide concentrations through stainless steel (SS) tubes $(1 / 4 \mathrm{in}$. OD by $5 \mathrm{~mm}$ ID by $8.9 \mathrm{~cm}$ in length) filled with $300 \mathrm{mg}$ Tenax TA 60/80 (Supelco, Bellefonte, PA, USA). Air sampling was accomplished using vacuum pumps (HX1 6902, Piot \& Tirouflet, France). The sampled air volume was measured with volumetric flow controllers (Gallius, Schlomberger), showing a flow rate between 1.1 and $1.8 \mathrm{~L} \mathrm{~min}^{-1}$. In the tunnel, the trapping system sampled a partial air stream from the main air stream in the wind tunnel. Because it was not possible to carry out multiple analysis of the samples, trapped pesticides being extracted by thermal desorption which destroys the sample during the analysis, and in order to select the best analysis range for the other samples, a reference tube was set up for some sampling periods in parallel to the outlet tube for the tunnel experiment and at $1.57 \mathrm{~m}$ above the soil for the field one. In addition, when volatilization was expected to be high (for the first sampling periods), a second tube was placed in series behind the tube to trap for breakthrough pesticide concentration. The trapping efficiency of Tenax appeared to be satisfactory for $S$-metolachlor and benoxacor as benoxacor was never detected in the second tube, and if $S$-metolachlor could be detected, it was in very small quantities compared to the concentration in the first tube $(<0.3 \%)$. Tenax tubes were stored with caps at $4{ }^{\circ} \mathrm{C}$ until analysis.

Soil sampling was performed using copper rings $(3 \mathrm{~cm}$ diameter, $2.2 \mathrm{~cm}$ height). At the beginning of the experiment, two soil samples were taken from the top soil outside the tunnel surfaces to estimate the $S$-metolachlor concentration in the soil. At the end of the experiment, ten samples were taken from inside each wind tunnel, two samples being taken at five distances equally distributed from the entrance to the exit of the tunnel. Then, the two samples of each distance were pooled. In the field, six samples were taken, distributed in the field, and pooled per two. Soil samples were immediately placed inside glass flasks tightly sealed with a screw cap with PTFE seal and refrigerated before extraction and analysis.

\section{Chemical analysis}

Spray solution sample was diluted with acetone $(5 \mu \mathrm{L}$ within $5 \mathrm{~mL}$ ), and $1 \mu \mathrm{L}$ was deposited on a Tenax tube to be further analyzed in a similar way as the air samples. The filters were shaken for $22 \mathrm{~h}$ with $200 \mathrm{~mL}$ hexane, and $1 \mu \mathrm{L}$ was deposited on a Tenax tube as well.

Prior to use, Tenax TA tubes were heated at $330{ }^{\circ} \mathrm{C}$ for 10 min to remove traces of organic compounds and minimize background peaks. Each calibration solution in acetone was spiked $(1 \mu \mathrm{L})$ on SS tubes packed with Tenax TA. Tubes were then immediately transferred to the autosampler for analysis. Thermal desorption of the analytes was performed using an automatic thermal desorption device Gerstel TDS3/TDSA2 (Gerstel GmbH \& Co. KG, Mülheim an der Ruhr, Germany) coupled with a transfer line to a cooled injection system (CIS, Gerstel GmbH \& Co. KG). The CIS was equipped with an empty straight glass liner and was cooled with liquid carbon dioxide during the thermal desorption process to cryo-focus analytes prior to transfer to a capillary column. Two methods were used for trace and highly concentrated compounds (splitless and split method, respectively). The two methods differed by the operating conditions of the CIS. The CIS was operated in the solvent vent mode to introduce the entire sample into the capillary column with the splitless method, while it was operated with split to transfer only a small part of the sample with the split method.

The thermal desorption device was interfaced to an Agilent 6890 GC coupled to an Agilent 5975C MS operated in electron impact ionization (EI) mode $(70 \mathrm{eV})$. The $\mathrm{GC}$ system was equipped with a CIS. Chromatographic separation was performed on a Rtx-PCB capillary column $(60 \mathrm{~m} \times 0.25 \mathrm{~mm}$ ID, $0.25 \mu \mathrm{m}$ film thickness) supplied by Restek. Helium was used as column carrier gas at a constant flow rate of $2.0 \mathrm{~mL} \mathrm{~min}^{-1}$. Chromatographic separation was carried out with the following oven temperature program: $50{ }^{\circ} \mathrm{C}$ (hold $2 \mathrm{~min}$ ) and ramp at $20^{\circ} \mathrm{C} \min ^{-1}$ to $310^{\circ} \mathrm{C}$ (hold $10 \mathrm{~min}$ to reach an analysis time of $25 \mathrm{~min}$ ). The interface, ion source, and quadrupole temperatures were fixed at 300,250 , and $150{ }^{\circ} \mathrm{C}$, respectively. The mass spectrometer was operated in selective ion monitoring (SIM) mode. The two most intense and specific ions of each compound were used for quantification. All this information is summarized in Table S2 of Supporting Information.

In this study, we determined the limits of quantification (LOQs) for pesticide in the air as the lowest concentration for which the coefficient of variation $(\mathrm{CV})$ of replicate injections was lower than $20 \%$ and the signal-to-noise ratio $(S / N)$ greater than 10 (González et al. 2014). LOQs were estimated by analyzing desorption tubes spiked with decreasing amounts of the analytes. Instrumental LOQ of $100 \mathrm{pg}$ was obtained for both compounds. Quadratic calibration curves were established by spiking SS tubes packed with Tenax TA with at least four different amounts of each compound 
(examples of calibration points are provided in Supporting Information Table S3). The determination coefficients were higher than 0.999 for both compounds. After the analysis of the sample, the Tenax tubes were reheated and analyzed to check the efficiency of the thermal desorption process. Reanalysis of each sample showed no carryover.

The soil samples (about $24 \mathrm{~g}$ ) and crop residue samples (about $2 \mathrm{~g}$ ) were mixed with 10 and $1 \mathrm{~g}$ of Celite, respectively, and put into a $33-\mathrm{mL}$ stainless steel extraction cell. The remaining volume of the cells was filled with Fontainebleau sand. The extraction and analysis were performed as described by Aslam et al. (2014). Briefly, the cells were extracted with methanol with an accelerated solvent extraction system. The extracts were evaporated to dryness with a rotary evaporator and further dissolved with $1 \mathrm{~mL}$ methanol and $2 \mathrm{~mL}$ water. The analysis of $S$-metolachlor as well as its metabolites oxanilic acid (OA) and ethane sulfonic acid (ESA) was performed by ultra-high performance liquid chromatography coupled with tandem mass spectrometry. Quantification was performed with an external standard calibration. As for air samples, examples of calibration points are provided in Supporting Information Table S3. For soil residues, extraction recoveries including matrix effects were determined with additional tests on soil samples for $S$-metolachlor, OA, and ESA (Table S4). They were found close to $100 \%$ for $S$-metolachlor and below $70 \%$ for the metabolites, in agreement with previous experiments (Aslam et al. 2014). For crop residues, we used extraction recoveries of 75, 35, and $42 \%$ for $S$ metolachlor, OA, and ESA, respectively. These recoveries were obtained by Aslam et al. (2014) on decomposed maize residues assuming that extraction recoveries and matrix effects would be relatively similar for the maize and cover crop residues of our experiments. The concentrations of pesticides were corrected by the extraction recoveries to ensure trueness of the results. Limits of quantifications in soil and crop residue were $0.3 \mu \mathrm{g} \mathrm{kg}^{-1}$ for $S$-metolachlor and $0.2 \mu \mathrm{g} \mathrm{kg}^{-1}$ for OA and ESA, respectively.

\section{Results and discussion}

\section{Soil and climate conditions}

Soil surface temperature varied similarly from $10{ }^{\circ} \mathrm{C}$ at night to $30{ }^{\circ} \mathrm{C}$ at midday in both tunnels (Fig. 1a). Wind speeds measured in the wind tunnel with the hot film anemometers and recalculated at the soil surface were on average $1.32 \mathrm{~m} \mathrm{~s}^{-1}$ in T-MM1 and $1.17 \mathrm{~m} \mathrm{~s}^{-1}$ in T-MM3 with a $3 \%$ of coefficient of variation (the Pitot anemometer gave $1.24 \mathrm{~m} \mathrm{~s}^{-1}$ in $\mathrm{T}$ MM3). A $12 \%$ difference was therefore observed between both tunnels which decreased down to $6 \%$ if we chose the Pitot measurement in T-MM3. The bulk density $(0-0.05 \mathrm{~m})$ measured on the day of the application was 1342 and
$1341 \mathrm{~kg} \mathrm{~m}^{-3}$ for MM1 and MM3, respectively. Gravimetric soil water content measured on MM1 and MM3 was 0.15 and $0.21 \mathrm{~g} \mathrm{~g}^{-1}$ in the $0-0.05 \mathrm{~m}$ at the beginning of the experiment and decreased down to 0.06 and $0.17 \mathrm{~g} \mathrm{~g}^{-1}$ in the $0-0.02 \mathrm{~m}$ in T-MM1 and T-MM3, respectively, at the end of the experiment (Fig. 1b). At $0.05 \mathrm{~m}$ depth, TDR sensors showed that soil water content was stable under MM1 (around $0.082 \mathrm{~g} \mathrm{~g}^{-1}$ after conversion given the bulk density) as well as under MM3 (around $0.213 \mathrm{~g} \mathrm{~g}^{-1}$ ). At $0.1 \mathrm{~m}$ depth, soil water content measured with TDR sensors gave 0.131 and $0.233 \mathrm{~g} \mathrm{~g}^{-1}$ under TMM1 and T-MM3, respectively (using bulk density measured at $0-0.05 \mathrm{~m}$ ). Cumulated water evaporation was 4.1 and $9.3 \mathrm{~mm}$ in T-MM1 and T-MM3, respectively, showing thus a higher evaporation rate from soil covered by crop residues than from bare soil (see Fig. S2 in Supporting information). In the literature, the water evaporation from bare soil is generally found to be higher than evaporation from a soil with crop residue (Drury et al. 1999, Thierfelder et al. 2013). The higher evaporation rate found for MM3 than for MM1 might be linked to higher soil water content as shown by the gravimetric and TDR measurements, providing thus a larger water supply, with a similar soil surface temperature (around $1 \%$ of difference between both tunnels) and even a slightly lower wind speed. In the field, soil surface temperature increases generally at a lower rate at midday in case of crop residues at the soil surface (Davin et al. 2014).

Air temperature varied during the field campaign between 6 and $19{ }^{\circ} \mathrm{C}$, with considerable wind speed (up to $5.7 \mathrm{~m} \mathrm{~s}^{-1}$ at $2.5 \mathrm{~m}$ ). Soil surface temperature showed a pronounced diurnal cycle with high temperature at midday (close to $40{ }^{\circ} \mathrm{C}$ on the second day). The measured bulk density on the first day was $1026 \mathrm{~kg} \mathrm{~m}^{-3}$ (5\% of variation coefficient over the three replicates). The gravimetric soil water content in the $0-0.01 \mathrm{~m}$ (with the trowel) was very low and even decreased from $0.05 \mathrm{~g} \mathrm{~g}^{-1}$ on the first day to $0.02 \mathrm{~g} \mathrm{~g}^{-1}$ at the end of the experiment (Fig. 1c). Between 0 and $0.05 \mathrm{~m}$, the gravimetric soil water content was found to be $0.11 \mathrm{~g} \mathrm{~g}^{-1}$ at $7 \mathrm{~h} 35 \mathrm{TU}$ on the day of the application, in agreement with TDR measurements. A small rain occurred on the afternoon of the last day of the experiment $(2.7 \mathrm{~mm})$.

\section{Pesticide application}

With an application rate of 142 and $120 \mathrm{~L} \mathrm{ha}^{-1}$ for the tunnel and field experiment, respectively, and a solution concentration of $10.3 / 0.41$ and $9.3 / 0.37 \mathrm{~g} \mathrm{~L}^{-1}$ in $S$-metolachlor/ benoxacor compounds for each experiment, respectively, these led to an expected application dose of 1463/58.2 and $1116 / 44.4 \mathrm{~g} \mathrm{ha}^{-1}$ of $S$-metolachlor/benoxacor for each experiment. The theoretical ratio between $S$-metolachlor and benoxacor quantity in the commercial solution is 20 (400 g $S$-metolachlor for $20 \mathrm{~g}$ of benoxacor). 

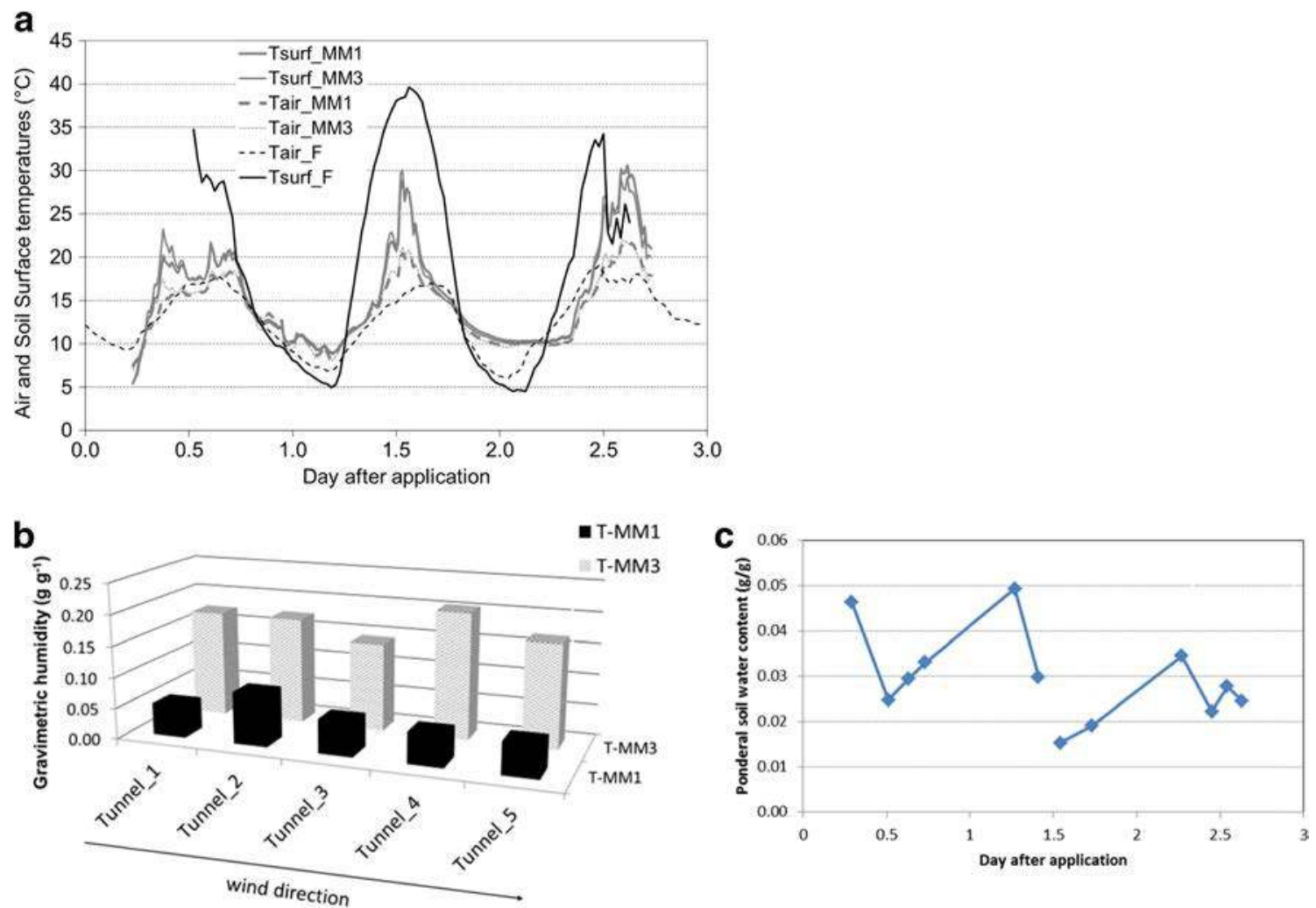

Fig. 1 a Soil surface temperatures with air temperatures for both experiment, $\mathbf{b}$ soil water content $\left(\mathrm{g} \mathrm{g}^{-1}\right)$ in the end of the wind tunnel experiment $(0-$ $2 \mathrm{~cm})$ at the five sampling locations, and $\mathbf{c}$ evolution of the soil water content with time $\left(\mathrm{g} \mathrm{g}^{-1}\right)$ in the field $(0-1 \mathrm{~cm})$

The analysis of the filters deposited on the soil during the application gave $682 / 34 \mathrm{~g} \mathrm{ha}^{-1}$ for T-MM1, $1683 / 73 \mathrm{~g} \mathrm{ha}^{-1}$ for T-MM3, and 848/28 $\mathrm{g} \mathrm{ha}^{-1}$ for the field experiment for $S$ metolachlor/benoxacor, respectively. The lower quantification for T-MM1 may be linked with the fact that three filters of the six were not well placed during the application run and thus biased the application rate. In the field, the measured application was 24 and $36 \%$ (Table 2) lower than the expected rate (given the solution concentration and the volume applied). Considerable wind speed (around $4.5 \mathrm{~m} \mathrm{~s}^{-1}$ at $3.65 \mathrm{~m}$ ) during application may have led to a significant drift thus biasing the application rate (Table 2).

\section{Pesticide concentration in the air and in the soil}

Concentrations of both compounds in the air were quantified in each sample of the tunnel outlets (Fig. 2). For both compounds, concentrations were higher at the outlet of T-MM3 than at the outlet of T-MM1, this difference being more pronounced just after application than on subsequent following days. The concentrations also showed a decrease with time, from, e.g., $920 \mathrm{ng} \mathrm{m}^{-3}$ down to $47 \mathrm{ng} \mathrm{m}^{-3}$ for $S$-metolachlor in T-MM3 and from 97 to $5 \mathrm{ng} \mathrm{m}^{-3}$ for benoxacor in T-MM3. Benoxacor concentrations were also always lower than $S$ metolachlor concentrations. Air concentrations could also be quantified at the inlet of the tunnel, in each sample for $S$ - metolachlor and only once for benoxacor (in the first sample of day 3). These concentrations were always lower than the concentrations at the outlet of the tunnel (around $1 \%$ of the concentrations at the outlet of the tunnels) except from the end of the second day when these concentrations could represent $14 \%$ of the concentrations at the outlet of the tunnels decreasing down to $2.4 \%$ for the last sample. This could be due to a treatment occurring close to the experimental farm.

Concentrations could also be quantified for both compounds in the field except for three samples for benoxacor. Similar results were observed from the field study to those from the tunnel experiment: concentrations in the air were higher just after application than during subsequent days, with higher concentrations in $S$-metolachlor than in benoxacor, with 334 and $5 \mathrm{ng} \mathrm{m}^{-3}$ found for $S$-metolachlor and benoxacor, respectively, for the first sample just after application. $S$-metolachlor concentrations could be quantified in all upwind samples, generally at a low level (a few percent of the concentration quantified in the field) except during the first night for which higher concentrations could be quantified (7.6 $\mathrm{ng} \mathrm{m}^{-3}$ to be compared with $45 \mathrm{ng} \mathrm{m}^{-3}$ on the field). This sample showed also a contamination with benoxacor $\left(0.65 \mathrm{ng} \mathrm{m}^{-3}\right)$ to be compared with $3 \mathrm{ng} \mathrm{m}^{-3}$ on the field.

Dealing now with pesticide residue found at the end of the experiments within the two first centimeters of soil (expressed as $\mathrm{g} \mathrm{ha}^{-1}$ ) or within the plant residues, only $S$-metolachlor and 


\begin{tabular}{|c|c|c|c|c|c|c|}
\hline \multirow[b]{2}{*}{$\mathrm{g} / \mathrm{ha}$} & \multicolumn{3}{|l|}{$S$-metolachlor } & \multicolumn{3}{|l|}{ Benoxacor } \\
\hline & T-MM1 & T-MM3 & field & T-MM1 & T-MM3 & Field \\
\hline Applied dose (theory) & 1500 & 1500 & 1500 & 75 & 75 & 75 \\
\hline Applied dose (solution) & 1462 & 1462 & 1117 & 58 & 58 & 44 \\
\hline Applied dose (measured) & 681 & 1683 & 848 & 33 & 74 & 28 \\
\hline Cumulative volatilization & $85(69-101)^{\mathrm{a}}$ & $148(120-176)^{\mathrm{a}}$ & 31 & $11(9-13)^{\mathrm{a}}$ & $14(11-17)^{\mathrm{a}}$ & 0.5 \\
\hline Residue in the top soil & $289(48 \%)^{\mathrm{b}}$ & $235(25 \%)^{\mathrm{b}}$ & $287(27 \%)$ & $-{ }^{\mathrm{b}}$ & & \\
\hline Residue on crop residue ${ }^{c}$ & - & 78 & - & & & \\
\hline Detection of OA and ESA (soil) & ESA a little & Yes OA and ESA & No & & & \\
\hline Detection of OA and ESA (crop residue) & - & A little $\mathrm{OA}$ and ESA & - & & & \\
\hline$\%$ drift estimation ${ }^{\mathrm{d}}$ & & & 24 & & & 36 \\
\hline$\%$ volatilization/solution ${ }^{\mathrm{d}}$ & 6 & 10 & 2.8 & 19 & 24 & 1.1 \\
\hline$\%$ volatilization/measured ${ }^{\mathrm{d}}$ & 12 & 9 & 3.7 & 33 & 19 & 1.8 \\
\hline
\end{tabular}

${ }^{a}$ Range of variation given the $19 \%$ variation coefficient observed between three wind tunnels under the same conditions after trifluralin application on bare soil (Bedos et al. 2002)

${ }^{\mathrm{b}}$ Variation coefficient over the five samples in the wind tunnel and three samples in the field

${ }^{\mathrm{c}}$ The conversion from the chemical analysis quantification given as gram of compounds per gram of crop residue was based on a crop residue coverage of $1300 \mathrm{~kg} \mathrm{ha}^{-1}$

${ }^{\mathrm{d}}$ Percent of applied dose (solution). The spray drift was estimated given the ratio between the measured applied dose and the expected one given the concentration in the applied solution

its metabolites ESA and OA were analyzed. Figure 3 shows that the level of residue in $S$-metolachlor was of the same order of magnitude in T-MM1 (289 $\mathrm{g} \mathrm{ha}^{-1}$ with a coefficient of variation $(\mathrm{CV})$ of $48 \%$ over the five samples) and in the field (287 $\mathrm{g} \mathrm{ha}^{-1}$ with a CV of $25 \%$ over the five samples) and slightly lower in T-MM3 $\left(235 \mathrm{~g} \mathrm{ha}^{-1}\right.$ with a CV of $27 \%$ over the three samples). $S$-metolachlor was also quantified within the plant residue of T-MM3 at a level of $78 \mathrm{~g} \mathrm{ha}^{-1}$. Metabolites OA and ESA were only found in the soil of T-MM3 and within plant residues (Table 2). It has to be noticed that no $S$ metolachlor nor OA and ESA could be quantified in the soil

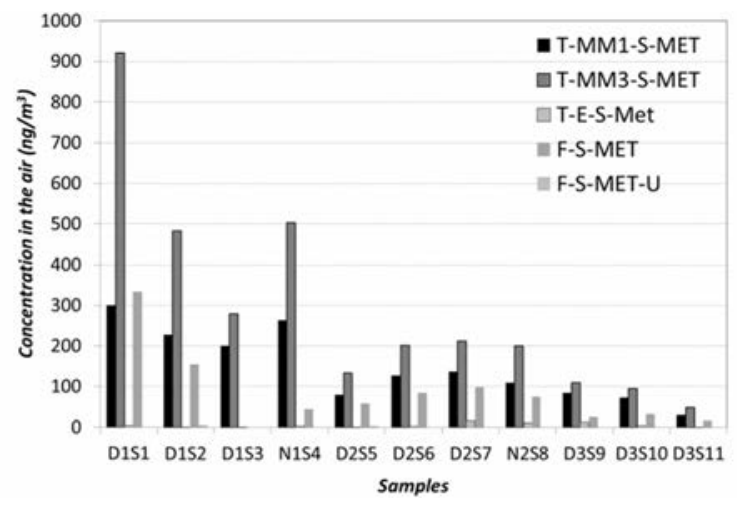

Fig. 2 Concentrations measured in the air $\left(\mathrm{ng} \mathrm{m}^{-3}\right)$ for each sample during the tunnel and the field experiments for $S$-metolachlor (left) and benoxacor (right) D1S1 is the sample number, it corresponds to the sample of day 1 sample no. 1 (cf Table S1 of Supporting Information before the experiment for the field experiment. They were detected in the soil of the tunnel experiment before the experiment, at a low level (less than $0.2 \%$ of the amount found at the end of the experiment for $S$-metolachlor and a few $\%$ for OA and ESA in T-MM3) potentially linked with application on the previous year. The fact that levels of OA and ESA quantified in T-MM3 in the end of the experiment were higher than those measured before the application and that no OA was quantified in T-MM1 in the end of the experiment and few ESA (lower than the amount of ESA found in T-MM3) shows that $S$-metolachlor degradation was faster in T-MM3.

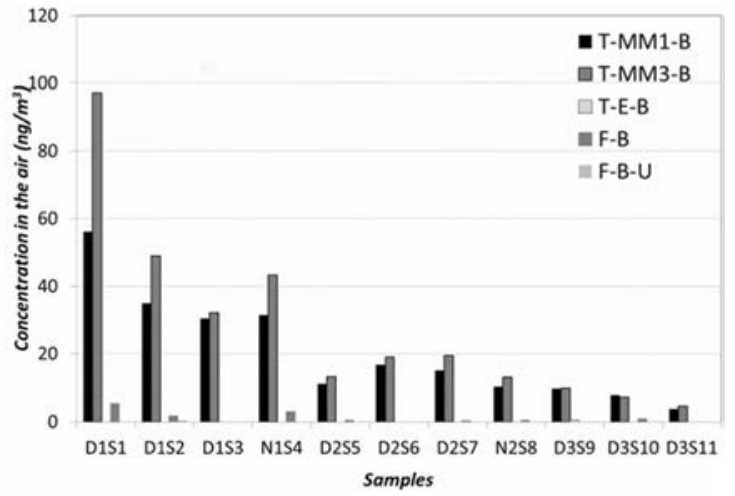

for details). T-MM1, T-MM3, and T-E correspond to the outlet of TMM1, T-MM3, and the entrance of the wind tunnel experiment. F- and F-X-U correspond to the field and upwind locations for the field experiment 


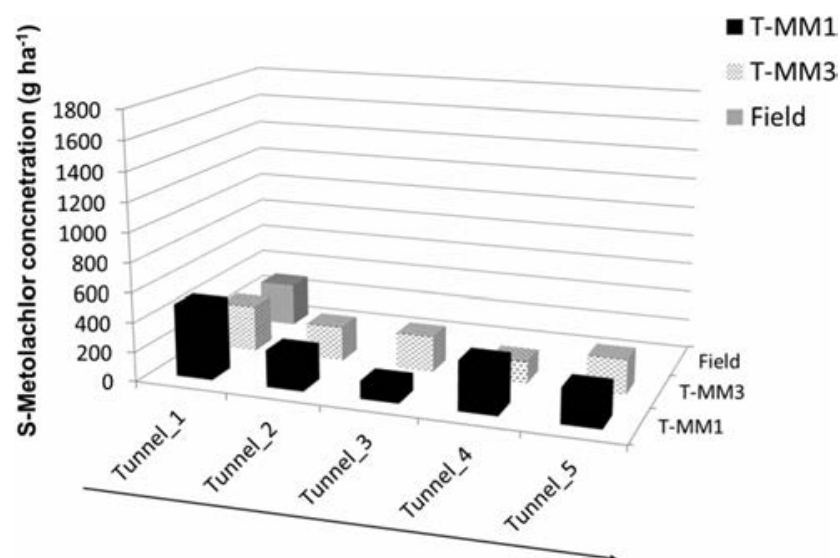

Fig. 3 Soil residue $\left(\mathrm{g} \mathrm{ha}^{-1}\right)$ in the first $2 \mathrm{~cm}$ of the soil in the end of the experiments (at the five sampling locations in T-MM1 and T-MM3: wind tunnel experiment for the MM1 and MM3 configuration, respectively; field for the field experiment). The black arrow gives the air flow direction within the wind tunnels for the wind tunnel experiment

\section{Pesticide volatilization}

Volatilization fluxes were quantified for both compounds and experiments that showed in general a distinct diurnal cycle. Maximum fluxes were observed just after application, at 77, 226, and $92 \mathrm{ng} \mathrm{m}^{-2} \mathrm{~s}^{-1}$ for $S$-metolachlor fluxes in T-MM1, TMM3, and in the field, respectively. These fluxes decreased with time to a few nanograms per square meter per second at the end of the experiment. Similar behavior was observed for benoxacor (Fig. 4). These fluxes led to the following $S$ metolachlor cumulated losses 3 days after application: $6 \%$ (T-MM1), $10 \%$ (T-MM3), and $2.8 \%$ (field) expressed as the applied dose calculated given the solution concentration (Table 2). For information, these ratios become 12, 9, and $3.7 \%$ when expressed as the applied dose measured on the filters. However, due to the problem mentioned above in the quantification of the applied dose with the filters in T-MM1, the cumulated volatilization calculated using the solution concentration was expected to be more reliable. All these results were in accordance with volatilization losses reported in the literature for $S$-metolachlor (Prueger et al. 2005; Rice et al.
2002). Indeed, $6.49 \%$ of the nominal application was found to be lost by volatilization after 21 days after application of metolachlor on a freshly tilled soil (Rice et al. 2002). Prueger et al. (2005) monitored over 5 days after application and for five different years (1998-2002) the metolachlor volatilization. Over the 5 years, the total percent of applied metolachlor lost to the atmosphere ranged from 5 to $25 \%$. Following the authors, this range of variation was associated to surface soil water, local meteorological conditions, and complex interactions between meteorological, soil, and chemical factors. These losses accounted for 19, 24, and $1.1 \%$ expressed as the applied dose calculated given the solution concentration when benoxacor is considered.

To compare the behavior of the two a.i., the ratio between $S$-metolachlor and benoxacor concentrations was calculated in each type of samples and compared to the theoretical ratio calculated in the commercial product, i.e., $400 \mathrm{~g}$ of $S$-metolachlor and $20 \mathrm{~g}$ of benoxacor, which leads to a theoretical ratio of 20 . In the applied solution, the ratio between the measured concentration in $S$ metolachlor and benoxacor was 25 for both experiments; on the filters used to estimate the application dose, this ratio was 21,23 , and 30 for T-MM1, T-MM3, and the field, respectively; for the concentrations in the air, the ratio was $7.9,11$, and 100 on average over time for $\mathrm{T}$ MM1, T-MM3, and the field, respectively (Fig. S3 in Supporting Information); for the cumulated volatilization fluxes, it was of 8,11 , and 62 for T-MM1, T-MM3, and the field, respectively. In the tunnel experiment, this ratio was lower for the air concentration samples (and thus the cumulated volatilization fluxes) than the one found in the applied solution showing a higher volatility for benoxacor than for $S$-metolachlor. On the contrary, in the field experiment, this ratio for the air concentration samples (and thus the cumulated volatilization fluxes) was higher than expected, showing thus a higher volatility for $S$ metolachlor than benoxacor in the field. Looking at the physicochemical characteristics of both compounds, the Henry law constant of benoxacor is slightly higher than
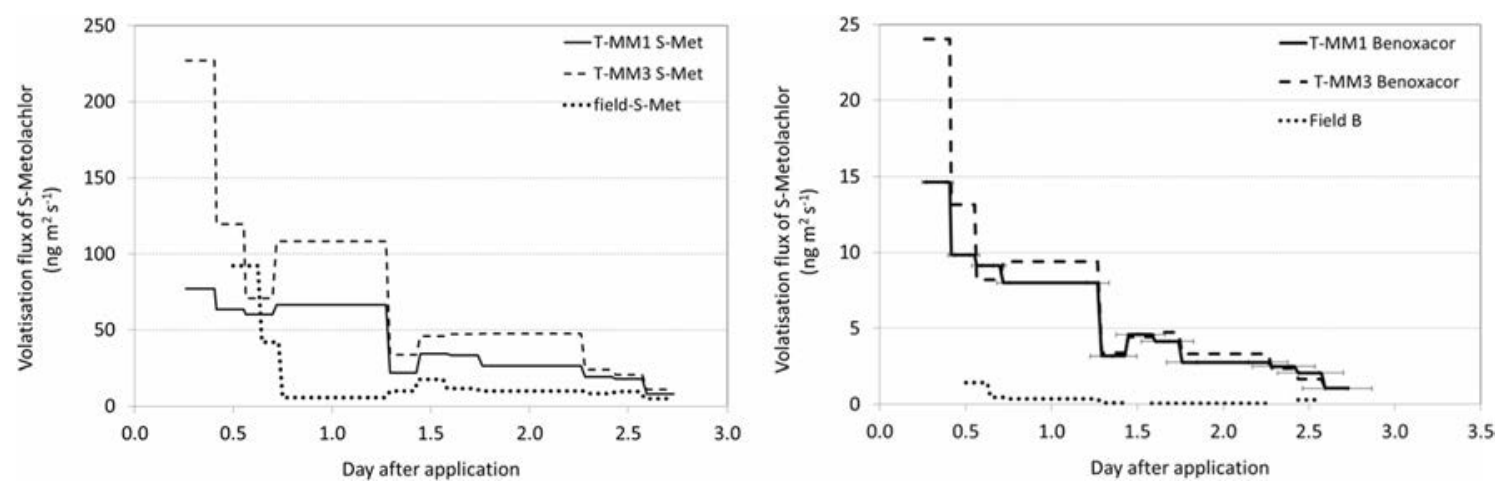

Fig. 4 Measured volatilization fluxes ( $\mathrm{ng} \mathrm{m}^{-2} \mathrm{~s}^{-1}$ ) with the wind tunnels and at the field scale for $S$-metolachlor (left) and benoxacor (right) (with $z_{0}=5 \mathrm{~mm}$ in FIDES-2D) 
the Henry law constant of $S$-metolachlor (7.7E-3 (at $20{ }^{\circ} \mathrm{C}$ ) and $2.2 \mathrm{E}-3 \mathrm{~Pa} \mathrm{~m}^{3} \mathrm{~mol}^{-1}$ (at $25^{\circ} \mathrm{C}$ ), respectively) and the $K_{\mathrm{oc}}$ of benoxacor is slightly lower than the $K_{\mathrm{oc}}$ of $S$-metolachlor $\left(<0.177\right.$ and $0.226 \mathrm{~m}^{3} \mathrm{~kg}^{-1}$, respectively). The soil organic matter contents were $2.4 \%$ in the tunnel and $2.8 \%$ in the field. Benoxacor should exhibit a higher volatility than $S$-metolachlor, which was the case in the tunnel experiment but not in the field. In the field, the benoxacor concentrations in the air were found to be small and often close to the quantification limit (0.1 ng trapped).

Even if the purpose of this study was not to compare quantitatively measured fluxes with both methods, we can note that cumulative volatilization fluxes were found to be higher within the wind tunnel TMM1 than in the field for both compounds. Such results were also noted by Sintermann et al. (2012), giving an explanation based on a generally higher friction velocity within the wind tunnel than under ambient conditions and on an oasis effect (which characterize conditions where, when there is a contrast between a humid and a dry zone surrounding, the water evaporation at the edge of the zone is larger than in the middle of the field because the incoming air is not equilibrated with the surface (Guyot 1998), generalized here to pesticide fluxes). This oasis effect may lead to an increase of $30 \%$ of the flux for a fetch of $2 \mathrm{~m}$ like in the wind tunnel. Further comparison would require additional tests on the effect of the sampling method at the outlet of the tunnel (here it was only at one location) as well as turbulence conditions within the tunnel as suggested by Loubet et al. (1999). We could additionally suggest that this difference could also be explained by the fact that the wind speed was constant in the tunnel all day and night (and also higher than the average one in the field), whereas ambient wind speed decreased during the nighttime in the field. These conditions resulted in a higher volatilization during the night periods as also noted by Genermont et al. 1998, more than one third of the total volatilization losses for the first night in the wind tunnel compared to less than $10 \%$ in the field conditions $(S$ metolachlor, Fig. S4 in Supplemental Information). Finally, it has also to be noticed that the soil surface conditions within the $0-0.01-\mathrm{m}$ depth were quite dry in the field exhibiting a diurnal variation (Fig. 1c). Such monitoring could not be done within the wind tunnel. The measurements at the end of the experiment showed also quite dry conditions within the 0 $0.02 \mathrm{~m}$ in T-MM1, but soil surface temperatures were lower than the one found in the field. The conditions found in the field, and to a lower extent in T-MM1, might have led to pesticide gaseous adsorption to the soil matrix which decreases the volatilization rates (Garcia et al. 2014). Calculations of the adsorption constant at $15{ }^{\circ} \mathrm{C}$ and $90 \%$ RH gave $2000 \mathrm{~m}^{3} \mathrm{~m}^{-2}$ for $S$-metolachlor and $20 \mathrm{~m}^{3} \mathrm{~m}^{-2}$ for benoxacor (K. Goss, personal communication). Such values showed that these compounds may exhibit a significant adsorption on the soil matrix under dry conditions, potentially reducing their volatility as long as dry conditions persisted. The significant impact of soil surface moisture on metolachlor volatilization was confirmed by Gish et al. (2009) who showed a decrease in volatilization rates under dry conditions.

Comparing now volatilization fluxes from bare soil to volatilization fluxes from soil covered with crop residues, differences were expected due to (1) differences in pesticide adsorption on soil and on crop residues: adsorption was expected to be higher on crop residue even if $K_{\mathrm{oc}}$ may be lower (Table 1) due to higher organic content of the mulch than the soil organic content; (2) differences in surface exchange between the atmosphere and the surface: crop residue represents a higher surface of exchange with the air than the soil surface as well as a higher roughness length; and (3) soil surface water content and temperature conditions: T-MM3 was found wetter than TMM1 and soil surface temperatures were similar even slightly higher in T-MM3 just after application. These effects might counterbalance each other. Indeed, if volatilization rates were found higher in T-MM3 than in T-MM1 just after application (this difference is even increased if volatilization flux was calculated given the Pitot anemometer), this difference decreased the days after, the effect of adsorption on plant residue being maybe higher and chemical degradation probably occurred. This higher initial volatilization rate led to a greater cumulative volatilization loss when the soil was covered by crop residue. The difference between the two tunnels was significant, mostly for $S$-metolachlor, if we take into account a coefficient of variation of $19 \%$ as calculated by Bedos et al. (2002b) when comparing trifluralin volatilization fluxes with three wind tunnels under the same conditions.

\section{Conclusion}

Based on experiments carried out with two experimental systems, this study provides two datasets with quantitative data on $S$-metolachlor volatilization rates (and its phytoprotector benoxacor) together with environmental conditions. A diurnal cycle could be observed, mostly at the field scale that decreased in magnitude with time. Soil surface dryness was also expected to have played a role in the volatilization rate as observed from bare soil. Indeed, with $S$-metolachlor showing a high calculated adsorption coefficient, the adsorption from the gas phase to the soil matrix may have occurred. Cumulated losses were found in agreement with those in the literature. Measurements carried out at the field scale could give a quantification of the volatilization fluxes under real conditions, whereas the quantifications with the wind tunnel systems are helpful to analyze the behavior of a compound under semicontrolled conditions, using several systems in parallel allows to quantify the effect of a given factor (differing from one wind tunnel to another one, e.g., an irrigation or the presence of crop residues on the soil such as in this study) on the 
behavior of the compound. The crop residues on soil surface were shown, under the conditions studied here, to modify the dynamics of the volatilization rates and to enhance the volatilization rate, mostly just after application. It also enhanced degradation since metabolites of $S$-metolachlor could be found as early as 3 days after application (no sampling was performed earlier) only in the case of the presence of crop residue on the soil surface.

Further studies are required to quantify the spray application intercepted by the crop residue and the subsequent dissipation of the pesticides within the crop residues. Increasing the frequency of air sampling in the air would also allow a better description of the diurnal cycle. Experiments under various conditions of soil surface water content are also required to understand processes occurring under dry conditions such as adsorption from the gas phase to the soil matrix. Improving knowledge on the volatilization process under conditions of current practices, such as conservation tillage, is necessary to improve emission models as well as to identify the best potential strategies to reduce such losses.

Acknowledgements The authors thank ANR MICMAC design (ANR 09 STRA 06) for funding, the experimental farm in Purpan (Toulouse, France), Laboratoire d'Etude et de Recherche en Environnement et Santé (LERES, Rennes, France, especially F. Mercier) for the chemical analysis of air and application dose samples, N. Bernet for technical support in soil sample analysis, and K. Goss (UFZ, Leipzig, Germany) for calculation of adsorption coefficients from gaseous phase.

\section{References}

Alletto L, Coquet Y, Benoit P, Heddadj D, Barriuso E (2010) Tillage management effects on pesticide fate in soils. A review. 2010. Agron Sustain Dev 30:367-400

Alletto L, Benoit P, Bolognési B, Couffignal M, Bergheaud V, Dumény V, Barriuso E (2013) Sorption and mineralisation of $S$-metolachlor in soils from fields cultivated with different conservation tillage systems. Soil Tillage Res 128:97-103. doi:10.1016/j.still.2012.11.005

Aslam, S., Garnier, P., Rumpel, C., Parent, S. E., \& Benoit, P. (2013). Adsorption and desorption behavior of selected pesticides as influenced by decomposition of maize mulch. Chemosphere, pp. 14471455.

Aslam S, Iqbal A, Deschamps M, Recous S, Garnier P, Benoit P (2014) Effect of rainfall regimes and mulch decomposition on the dissipation and leaching of $S$-metolachlor and glyphosate: a soil column experiment. Pest Manag Sci. doi:10.1002/ps.3803

Banks, P. A., \& Robinson, E. L. (1982). The influence of straw mulch on the soil reception and persistence of metribuzin. Wee, pp. 164-168.

Bedos C, Cellier P, Calvet R, Barriuso E, Gabrielle B (2002a) Mass transfer of pesticides into the atmosphere by volatilization from soils and plants: overview. Agronomie 22:21-33

Bedos C, Rousseau-Djabri MF, Flura D, Masson S, Barriuso E, Cellier P (2002b) Rate of pesticide volatilization from soil: an experimental approach with a wind tunnel system applied to trifluralin. Atmos Environ 36(39-40):5917-5925

Bedos, C., Rousseau-Djabri Loubet, B, Durand B., Flura D., Briand O., \& Barriuso E. (2010). Fungicide volatilization measurements: inverse modeling, role of vapor pressure, and state of foliar residue. Environmental Science \& Technology, 2522-2528.

Bescansa, P., Imaz, M., Virto, I., Enrique, A., \& Hoogmoed, W. (2006). Soil water retention as affected by tillage and residue management in semiarid Spain. Soil and Tillage Research, pp. 19-27.

Curran, W., Lebl, R., \& Simmons, F. (1992). Effects of tillage and application method on clomazone, imazaquin, and imazethapyr persistence. Wee, pp. 482-489.

Davin E, Seneviratne S, Ciais P, Olioso A, Wang T (2014) Preferential cooling of hot extremes from cropland albedo management. Proc Natl Acad Sci 111(27):9757-9761. doi:10.1073/pnas.1317323111

Drury, C., Tan, C., Welacky, T., Oloya, T., Hamill, A., \& Weaver, S. (1999). Red clover and tillage influence on soil temperature, water content, and corn emergence. Agro, pp. 101-108.

Fortin, M. (1993). Soil temperature, soil water, and no-till corn development following in-row residue removal. Agronomy Journal, pp. 571-576.

Garcia, L., Bedos, C., Génermont, S., Benoit, P., Barriuso, E., \& Cellier, P. (2014). Modeling pesticide volatilization from bare soil: additional effect of gaseous adsorption on soil solid surface. Environ Sci \& Technol., pp. 4991-4998.

Gaynor, J., Tan, C., Ng, H., Drury, C., Welacky, T., \& van Wesenbeeck, IJ (2000). Tillage and controlled drainage-subirrigated management effects on soil persistence of atrazine, metolachlor, and metribuzin in corn. Journal of Environmental Quality, pp. 936-947.

Genermont S, Cellier P, Flura D, Morvan T, Laville P (1998b) Measuring ammonia fluxes after slurry spreading under actual field conditions. Atmos Environ 32(3):279-284

Genermont, S., Flura, D., Cellier, P., (1998a). Ammonia loss reduction after slurry spreading by modification of the soil surface characteristics. World Fertilizer Congress, 7-13 September, 1997, Ghent, Belgium, Proceedings Volume no. II, pp. 488-497.

Ghadiri, H., Shea, P., Wicks, G., \& Haderlie, L. (1984). Atrazine dissipation in conventional-till and no-till sorghum. Journal of Environment Quality 549-552.

Gish TJ, Prueger JH, Kustas WP, Daughtry CST, McKee LG, Russ A, Hatfield JL (2009) Soil moisture and metolachlor volatilization observations over three years. J Environ Qual 38(5):1785-1795. doi: $10.2134 /$ jeq2008.0276

Giuliano, S., Ryan, M. R., Véricel, G., Rametti, G., Perdrieux, F., Justes, E., \& Alletto, L. (2016, in press). Low-input cropping systems to reduce input dependency and environmental impacts in maize production: a multi-criteria assessment. European Journal of Agronomy.

Glotfelty DE (1987) The effects of conservation tillage practices on pesticide volatilization and degradation. In: Logan TJ, Davidson JM, Baker JL, Overcash MR (eds) Effects of conservation tillage on groundwater quality: nitrates and pesticides. M.I.: Lewis Publ, Chelsea, pp. 56-62

González O, Blanco ME, Iriarte G, Bartolomé L, Maguregui MI, Alonso RM (2014) Bioanalytical chromatographic method validation according to current regulations, with a special focus on the non-well defined parameters limit of quantification, robustness and matrix effect. J Chromatogr A 1353:10-27

Goss KU, Bushmann J, Schwarzenbach R (2004) Adsorption of organic vapors to air-dry soils: model predictions and experimental validation. Environ Sci Technol 38(13):3667-3673

Gupta S, Schne E, Swan JB (1988) Planting depth and tillage interactions on corn emergence. Soil Science Society of America Journal, pp: $1122-1127$

Guyot, G. (1998). Physics of the Environment and Climate, Wiley. 632p.

Huang CH (1979) A theory of dispersion in turbulent shear flow. Atmos Environ 13:453-463

Isensee A, Sadeghi A (1994) Effects of tillage and rainfall on atrazine residue levels in soil. Wee, pp:462-467 
IUSS Working Group WRB. (2007). Word reference base for soil resources 2006, first update 2007. (No. Reports No. 103). Rome: FAO.

Locke MA (1992) Sorption-desorption kinetics of alachlor in surface soil from two soybean tillage systems. Journal of Environment Quality: $558-566$

Loubet B, Cellier P, Flura D, Génermont S (1999) An evaluation of the wind-tunnel technique for estimating ammonia volatilization from land: part 1. Analysis and improvement of accuracy. J Agric Eng Res 72:71-81

Loubet, B., Génermont, S., Ferrara, R., Bedos, C., Decuq, C., Personne, E., Cellier, P. (2010). An inverse model to estimate ammonia emissions from fields. European Journal of Soil Science, pp. 793-805.

Loubet B, Milford C, Hensen A, Daemmgen U, Erisman J-W, Cellier P, Sutton MA (2009) Advection of NH3 over a pasture field, and its effect on gradient flux measurements. Biogeosciences Discuss 6: 163-196

Loubet B, Milford C, Sutton AA, Cellier P (2001) Investigation of the interaction between sources and sinks of atmospheric ammonia in an upland landscape using a simplified dispersion-exchange model. J Geophys Res 106(D20):24,183-24,195

Loubet, B., Panic, I., Bedos, C., Briand, O., Seux, R., \& Cellier, P. (2006). Local deposition of volatilised pesticides may be as large as drift. A modelling study. Presented at the Pesticides Behaviour in Soils, Water and Air.

Miyamoto, T., Kobayashi, R., Annaka, T., \& Chikushi, J. (2001). Applicability of multiple length TDR probes to measure water distributions in an Andisol under different tillage systems in Japan. Soil And, pp. 91-99.

Philip JR (1959) The theory of local advection: 1. J Meteorol 16:535-547

Prueger JH, Gish TJ, McConnell LL, McKee LG, Hatfield JL, Kustas WP (2005) Solar radiation, relative humidity, and soil water effects on metolachlor volatilization. Environ Sci \& Technol 39:5219-5226

Reddy, K. N., \& Locke, M. A. (1998). Sulfentrazone sorption, desorption, and mineralization in soils from two tillage systems. Weed Science, pp. 494-500

Rice CP, Nochetto CB, Zaza P (2002) Volatilization of trifluralin, atrazine, metolachlor, chlorpyrifos, alpha-endosulfan, and betaendosulfan from freshly tilled soil. J Agric Food Chem 50(14): 4009-4017
Sadeghi, A., \& Isensee, A. (1996). Impact of reversing tillage practices on movement and dissipation of atrazine in soil. Soil Science, pp. 390 397.

Sadeghi, A., \& Isensee, A. (1997). Alachlor and cyanazine persistence in soil under different tillage and rainfall regimes. Soil Science, pp. 430-438.

Sintermann J, Neftel A, Ammann C, Häni C, Hensen A, Loubet B, Flechard CR (2012) Are ammonia emissions from field-applied slurry substantially over-estimated in European emission inventories? Biogeosciences 9(5):1611-1632. doi:10.5194/bg-9-1611-2012

Tallec, T., Béziar, P., Jarosz, N., Rivalland, V., \& Ceschia, E. (2013). Crops' water use efficiencies in temperate climate: comparison of stand, ecosystem and agronomical approaches. Agricultural and Forest Meteorology, pp. 69-81.

Thierfelder C, Mwila M, Rusinamhodzi L (2013) Conservation agriculture in eastern and southern provinces of Zambia: long-term effects on soil quality and maize productivity. Soil Till Res 126:246-258

Wahl, D. A., \& Stobbe, E. H. (1984). The effect of tillage on soil temperature and corn (Zea mays L.) growth in Manitoba. Canadian Journal of Plant Science, pp. 59-67.

Weber, J., Hardy, D., \& Leidy, R. (2002). Laboratory, green-house, and field lysimeter studies of 14C-atrazine volatilization. In Pesticide environmental fate. (Phelps W, Winton K, Effland WR, editors., pp. 125-142). Washington, DC: ACS Symp. Ser. 813. Am. Chem. Soc.

Weber, J., Taylor, K. A., \& Wilkerson, G. G. (2006). Soil cover and tillage influenced metolachlor mobility and dissipation in field lysimeters. Agronomy Journal, pp. 19-25.

Whang JM, Schomburg CJ, Glotfelty DE, Taylor AW (1993) Volatilization of fonofos, chlorpyrifos, and atrazine from conventional and no-till surface soils in the field. J Environ Qual 22:173180

Wienhold BJ, Gish TJ (1994) Effect of formulation and tillage practice on volatilization of atrazine and alachlor. J Environ Qual 23:292-298

Xu, D., \& Mermoud, A. (2001). Topsoil properties as affected by tillage practices in North China. Soil and Tillage Research, pp. 11-19.

Zablotowics, R., Locke, M. A., Gaston, L. A., \& Bryson, C. T. (2000). Interactions of tillage and soil depth on fluometuron degradation in a Dundee silt loam soil. Soil and Tillage Research, pp. 61-68. 